\title{
Transitional care from hospital to home for older people: implementation of best practices
}

\author{
Transição do cuidado da pessoa idosa internada para o domicílio: implementação de melhores práticas \\ Transición del cuidado del adulto mayor internado para el hogar: implementación de buenas prácticas
}

\section{Maria Fernanda Baeta Neves Alonso da Costa' ORCID: 0000-0002-2763-8050 \\ Karina Sichieri" ORCID: 0000-0002-5074-4636 \\ Vanessa de Brito Poveda"' ORCID: 0000-0002-5839-7253 \\ Cleide Maria Caetano Baptista " ORCID: 0000-0002-3916-7700 \\ Priscila Cantoni Aguado" ORCID: 0000-0003-4520-5969}

'Universidade Federal de Santa Catarina. Florianópolis, Santa Catarina, Brazil.

"Universidade de São Paulo, Hospital Universitário. São Paulo, São Paulo, Brazil.

I'Universidade de São Paulo. São Paulo, São Paulo, Brazil.

How to cite this article: Costa MFBNA, Sichieri K, Poveda VB, Baptista MC, Aguado PC. Transitional care from hospital to home for older people: implementation of best practices. Rev Bras Enferm. 2020;73(Suppl 3):e20200187. doi: http://dx.doi.org/10.1590/0034-7167-2020-0187

\section{Corresponding author:}

Maria Fernanda Baeta Neves Alonso da Costa E-mail: fernanda.baeta@ufsc.br

EDITOR IN CHIEF: Dulce Barbosa ASSOCIATE EDITOR: Fátima Helena Espírito Santo

Submission: 03-22-2020

Approval: 08-07-2020

\section{ABSTRACT}

Objective: to assess the conformity of nursing care concerning best evidence in transitional care from hospital to home for older people. Methods: a project to implement best evidence based on the model proposed by the Joanna Briggs Institute in surgical clinic of a university hospital with older people, caregivers or family members, and nurses, between July and August 2019. Eight evidence-based criteria have been audited through interviews, medical records and computerized system, presented in percentages. Results: the highest non-compliance rate found in a baseline audit was absence of continued training on transitional care and hospital discharge plan. Identifying barriers to best practices included educational programs; afterwards, there was an improvement in compliance rates in all the criteria assessed. Final considerations: the criteria based on audited evidence showed an increase in compliance rates with the strategies implemented, contributing to improving transitional care for older people. Descriptors: Primary Health Care; Patient Discharge; Continuity of Patient Care; Nursing; Transitional Care.

\section{RESUMO}

Objetivo: avaliar a conformidade da assistência de enfermagem em relação às melhores evidências na transição do cuidado da pessoa idosa internada em hospital para o domicílio. Métodos: projeto de implementação de melhores evidências, a partir do modelo Joanna Briggs Institute, em hospital universitário, com idosos, cuidadores e enfermeiros, entre julho e agosto de 2019. Foram auditados oito critérios baseados em evidências, por meio de entrevistas, prontuário e sistema informatizado, apresentados em percentuais. Resultados: na auditoria de base, o maior índice de não conformidade foi a ausência de formação continuada sobre transição do cuidado e plano de alta hospitalar. A identificação das barreiras às melhores práticas incluiu programas educativos. Após, verificou-se melhora nos índices de conformidade em todos os critérios avaliados. Considerações finais: os critérios baseados em evidências auditados apresentaram ampliação nos índices de conformidade com as estratégias implementadas, contribuindo para melhora da transição do cuidado da pessoa idosa.

Descritores: Atenção Primária à Saúde; Alta do Paciente; Continuidade da Assistência ao Paciente; Enfermagem; Cuidado de Transição.

\section{RESUMEN}

Objetivo: evaluar la conformidad de los cuidados de enfermería en relación a la mejor evidencia en la transición del cuidado de los ancianos ingresados en un hospital al domicilio. Métodos: proyecto de implementación de mejor evidencia, basado en el modelo del Joanna Briggs Institute, en un hospital universitario, con ancianos, cuidadores y enfermeras, entre julio y agosto de 2019. Se auditaron ocho criterios basados en evidencia a través de entrevistas, historias clínicas y sistema informático, presentado en porcentajes. Resultados: en la auditoría de línea de base, la mayor tasa de incumplimiento fue la ausencia de capacitación continua sobre transición de atención y plan de alta hospitalaria. La identificación de barreras a las mejores prácticas incluyó programas educativos. Posteriormente, hubo una mejora en las tasas de cumplimiento en todos los criterios evaluados. Consideraciones finales: los criterios basados en evidencia auditada mostraron un aumento en las tasas de cumplimiento de las estrategias implementadas, contribuyendo a mejorar la transición de la atención a las personas mayores.

Descriptores: Atención Primaria de Salud; Alta del Paciente; Continuidad de la Atención al Paciente; Enfermería; Cuidado de Transición. 


\section{INTRODUCTION}

As the Brazilian population over 60 has been growing, changes in health standards are being established, such as decrease in morbidity and mortality from infectious diseases and an increase in the prevalence of chronic non-communicable diseases. Thus, care models that adequately respond to chronic conditions should be implemented. Considering this new agenda, many countries have been reformulating their health systems, redirecting them to an integrated structure focused on strengthening Primary Health Care (PHC) and comprehensive care ${ }^{(1-3)}$.

Chronic diseases, now considered a true epidemic, are intensified by an accelerated demographic transition worldwide. It is observed that the proportion of people aged 65 and older has doubled in a period of just two decades, increasing the expansion of the percentage of people older than 65 years old from $2.7 \%$ in 1960 to $5.4 \%$ in 2000. Estimates show that this number will reach $19 \%$ in 2050 , thus surpassing the number of young people ${ }^{(4)}$.

Studies carried out in the United States estimate that at least $20 \%$ of the older people with five or more chronic conditions require hospitalization, presenting complex health problems and requiring transitional care to home. Transitional care is a broad term that promotes the safe and timely transfer of patients between levels of care. It includes activities from admission, hospital discharge and immediate post-discharge follow-up, and can be considered part of integrated care and a program to prevent readmission. Therefore, transitional care has several essential elements, such as communication between professionals about hospital discharge; discharge plan development; patient and caregiver preparation for transitional care; medication adherence; post-discharge follow-up; patient education on self-management/self-care ${ }^{(5)}$.

The success of transitional care, especially for older people, depends on hospital discharge planning, post-discharge monitoring, and home support, thus decreasing preventable adverse events such as medication errors, falls, and postoperative infections. Transitional care, when performed with quality, reduces the rates of readmission. A systematic review showed that six out of 12 studies conducted in the United States of America, Denmark, France, and Australia, there was a decrease in the length and rate of readmission in a period of up to six months after hospital discharge ${ }^{(5)}$.

Professionals should prepare patients and their caregivers so that they can keep up with care constantly and become actively engaged in decisions related to care plan development and execution $^{(6-7)}$.

Studies indicate that it is necessary to carry out individualized discharge planning at each hospitalization, with participation of health professionals, older people, family members/caregivers, and a quality transitional care for home $\mathrm{e}^{(8-9)}$.

A survey of extra-hospital resources must be carried out by nurses so that they can make sure that, after discharge, patients will receive care according to their needs. Resources refer to the presence of a primary care unit, a family physician, a nurse who will be able to continue hospital care, availability of equipment, medications needed to treat a patient, among others ${ }^{(8)}$.

Nurses should guide patients and their families about the need to continue treatment, engaging other care team members in this transition process in favor of joint action and more qualified care ${ }^{(10)}$.

Several strategies can be adopted at hospital discharge as a system for sharing information between hospital and health unit; discharge planning; case management; post-discharge follow-up by telephone; contact phone of the nurse in charge of care during hospitalization; printed care plan; written educational material; brochures with phones and community service websites ${ }^{(11)}$.

Thus, this project aims to improve practices regarding transitional care from hospital to home for older people and to build a discharge plan protocol in a university hospital in São Paulo using the evidence implementation model, developed by the Joanna Briggs Institute, clinical audit and feedback from JBI (PACES) ${ }^{(12)}$, to promote better quality care and bring better results to the health of this population.

\section{OBJECTIVE}

To assess the conformity of nursing care concerning best evidence in transitional care from hospital to home for older people.

\section{METHODS}

\section{Ethical aspects}

This project was approved by an Ethics Committee, according to the Resolution 466/12 and the Brazilian National Health Council (Conselho Nacional de Saúde) guidelines, guaranteeing data confidentiality and secrecy as well as participant anonymity. Participants who agreed to participate in the project signed two copies of the Informed Consent Form (ICF); the project leader stayed with one copy, and the research participant, with the other.

\section{Design, place of study, and period}

This project aiming at implementing best evidence based used the Joanna Briggs Institute (JBI) audit and feedback tool: "JBI Practical Application of Clinical Evidence System" (PACES) and "Getting Research into Practice" (GRiP) $)^{(13)}$. The three phases of this tool were followed: establishing a team for the project and carrying out a basic audit, based on the criteria informed by evidence; analyzing the results of a baseline audit, planning and implementing strategies aimed at improving non-conformities found in a baseline audit, with the help of GRiP; conducting a follow-up audit to assess the results of interventions implemented to improve practice and identify future issues to be addressed in subsequent audits.

This study was developed in a public teaching hospital with secondary care complexity, with 153 beds distributed for medicine, surgery, pediatrics, and obstetrics, based in the west of the city of São Paulo, Brazil. Data collection took place in surgical clinic unit, which has 27 operational beds and is intended for caring for adult patients who need general or orthopedic surgery.

An average of 40 older people (aged 60 and over) were admitted monthly to surgical clinic between April 1, 2018 and March 6,2019 for surgical treatment. Hospitalizations occurred due to fractures $(81 ; 18.2 \%)$, hernia $(66 ; 14.8 \%)$, and cholelithiasis $(28$; $8.5 \%)$. Most were between 60 and 69 years old (190; 42.7\%); 70 
and 79 years older (136; 30.5\%); 80 and 89 years (106; $23.8 \%) ; 90$ and 99 years old $(12 ; 2.7 \%)$; and 100 years and older $(1 ; 0.2 \%)$.

The surgical clinic nursing staff comprises a head nurse, 13 assistant nurses and 26 nursing assistants/technicians, distributed in four work shifts.

The surgical clinic unit uses patient classification systems (PCS) ${ }^{(14)}$, according to the nursing care needs, in different types of care: minimal, intermediate, highly dependent and intensive. Nurses and nursing residents are responsible for the Nursing Process (patient assessment, survey of nursing diagnoses, and nursing care planning, execution and assessment) as well as providing care; nursing technicians are responsible for providing nursing care. The study was carried out between March and September 2019.

\section{Population: inclusion and exclusion criteria}

The sample consisted of seven older patients admitted to surgical clinic aged 60 and over and 10 nurses from the surgical clinic working at the unit. Those who were on vacation or sick leave, as well as nurses who were part of this implementation team have been excluded.

\section{Study protocol}

The first phase was to set up the audit team, composed of the leader of this implementation project, responsible for planning, supervising and coordinating the clinical audit process and implementing best practices in transitional care from hospital to home for older people; nurses in the audited unit; Teaching and Quality Service (Serviço de Ensino e Qualidade) nurses, who assisted in planning an audit, developing a hospital discharge protocol, in data collection, in planning and executing tools to implement best practices and professional training.

To determine current levels of compliance with the recommendations of best practices in the transitional care of older people admitted to a hospital for the home, this project used eight audit criteria included in the JBI PACES program ${ }^{(12)}$. Chart 1 presents the evidence-based best practice recommendations for auditing.

A baseline audit took place for 15 days from July 1, 2019. For data collection, an instrument was built to check whether the audited criteria were in compliance with the evidence-based recommendations or not.

Chart 1 - Audit criteria, sample and approach for measuring compliance with best practices, São Paulo, Brazil, 2019

\begin{tabular}{|c|c|c|}
\hline Audit criteria & Sample & Method used to measure (\%) of compliance with best practices \\
\hline $\begin{array}{l}1 \text { - All staff involved in transitional } \\
\text { care have received education } \\
\text { regarding transitional care } \\
\text { from hospital to home for older } \\
\text { people. (10 of } 10 \text { samples taken) }\end{array}$ & $\begin{array}{l}\text { Nurses } \\
\text { Baseline audit: } 10 \\
\text { Follow-up audit: } 08\end{array}$ & $\begin{array}{l}\text { A questionnaire sent by Survey Monkey and Google Platform (form). } \\
\text { Question: have you received training on transitional care in the past six } \\
\text { months? } \\
\text { It will be considered compliant if professional answers yes. }\end{array}$ \\
\hline $\begin{array}{l}2 \text { - Patients/caregivers have } \\
\text { received education regarding } \\
\text { self-management interventions. } \\
\text { (7 of } 7 \\
\text { samples taken) }\end{array}$ & $\begin{array}{l}\text { Older people or caregivers/family } \\
\text { members admitted to surgical } \\
\text { clinic } \\
\text { Baseline audit: } 07 \\
\text { Follow-up audit: } 04\end{array}$ & $\begin{array}{l}\text { Interview with older person, caregiver/family: } \\
\text { Question: did you receive education about self-care at hospital discharge? } \\
\text { Yes ( ) } \\
\text { No ( ) } \\
\text { The criterion will be considered fulfilled when older people, caregivers/family } \\
\text { members answer affirmatively. }\end{array}$ \\
\hline $\begin{array}{l}3 \text { - An individualized discharge } \\
\text { plan has been documented for } \\
\text { all patients transitioning from } \\
\text { hospital to home. ( } 7 \text { of } 7 \text { samples } \\
\text { taken) }\end{array}$ & $\begin{array}{l}\text { Medical records of older patients } \\
\text { admitted to surgical clinic. } \\
\text { Baseline audit: } 07 \\
\text { Follow-up audit: } 04\end{array}$ & $\begin{array}{l}\text { Was a discharge plan documented in nursing progress notes for hospital to } \\
\text { home transition? } \\
\text { Yes ( ) } \\
\text { No () } \\
\text { The criterion will be considered fulfilled when discharge is recorded in the } \\
\text { patient's medical record. }\end{array}$ \\
\hline $\begin{array}{l}4 \text { - Patients/caregivers have } \\
\text { been involved in the discharge } \\
\text { planning process. (7 of } 7 \text { samples } \\
\text { taken) }\end{array}$ & $\begin{array}{l}\text { Older people or caregiver/family } \\
\text { member admitted to the surgical } \\
\text { clinic. } \\
\text { Baseline audit: } 07 \\
\text { Follow-up audit: } 04\end{array}$ & Interview: Readiness for Hospital Discharge Scale adapted ${ }^{(15)}$. \\
\hline $\begin{array}{l}5 \text { - Transitional care services have } \\
\text { been coordinated between the } \\
\text { hospital and community setting. } \\
\text { ( } 7 \text { of } 7 \text { samples taken) }\end{array}$ & $\begin{array}{l}\text { Patient system } \\
\text { (Computerized System) } \\
\text { Baseline audit: } 07 \\
\text { Follow-up audit: } 04\end{array}$ & $\begin{array}{l}\text { Check whether the return appointment was made at the HU-USP's outpatient } \\
\text { clinic, after hospital discharge, in the hospital's computerized system. } \\
\text { Yes ( ) } \\
\text { No () } \\
\text { It will be considered compliant if there is in the scheduling system the schedule of } \\
\text { the return with medical or nursing staff. }\end{array}$ \\
\hline
\end{tabular}




\begin{tabular}{|c|c|c|}
\hline Audit criteria & Sample & Method used to measure (\%) of compliance with best practices \\
\hline $\begin{array}{l}6 \text { - Patient care needs have } \\
\text { been communicated between } \\
\text { the hospital and community } \\
\text { healthcare providers. ( } 7 \text { of } 7 \\
\text { samples taken) }\end{array}$ & $\begin{array}{l}\text { Medical records of older patients } \\
\text { admitted to surgical clinic. } \\
\text { Baseline audit: } 07 \\
\text { Follow-up audit: } 04\end{array}$ & $\begin{array}{l}\text { The needs for patient care are documented in nursing progress notes at discharge. } \\
\text { Yes () } \\
\text { No () } \\
\text { The criterion will be considered fulfilled if there is medical record registry. }\end{array}$ \\
\hline $\begin{array}{l}7 \text { - Post discharge follow-up has } \\
\text { occurred. ( } 7 \text { of } 7 \text { samples taken) }\end{array}$ & $\begin{array}{l}\text { Patient System } \\
\text { (Computerized System) } \\
\text { Baseline audit: } 07 \\
\text { Follow-up audit: } 04\end{array}$ & $\begin{array}{l}\text { Check in the computerized patient system if there was an outpatient nursing } \\
\text { and/or physician return. } \\
\text { Yes () } \\
\text { No () } \\
\text { The criterion will be considered fulfilled if a patient returned at the scheduled } \\
\text { outpatient appointment. }\end{array}$ \\
\hline $\begin{array}{l}8 \text { - A multifaceted, approach } \\
\text { is used for transitioning older } \\
\text { people from hospital to home } \\
\text { (e.g. may include telephone } \\
\text { follow-up, home-based exercise } \\
\text { programs, patient-centered } \\
\text { discharge instruction) ( } 7 \text { of } 7 \\
\text { samples taken). }\end{array}$ & $\begin{array}{l}\text { Older people or caregivers/ } \\
\text { family members admitted to the } \\
\text { surgical clinic } \\
\text { Baseline audit: } 07 \\
\text { Follow-up audit: } 04\end{array}$ & $\begin{array}{l}\text { Interview with older people } \\
\text { Question: did you receive guidance on general care, information leaflets, } \\
\text { demonstration/participation in procedures, return to the outpatient clinic, } \\
\text { medical prescription (medication use). } \\
\text { Yes ( ) } \\
\text { No () } \\
\text { The criterion will be considered fulfilled if older people or caregivers/family } \\
\text { members answer yes }\end{array}$ \\
\hline
\end{tabular}

\section{Analysis of results, and statistics}

In phase two, all project team analyzed the baseline audit results, and strategies have been discussed to increase the level of compliance with the audited criteria. GriP was used to document all barriers encountered, aiming to seeking strategies and resources to overcome them and improve the level of compliance. The GRiP results are reported in the results section of Chart 2 .

The main actions developed were: development of discharge educational leaflets containing the concept, general care and care for the surgical wounds of herniorrhaphy, cholecystectomy and hip fracture surgeries; training of surgical clinic nurses on best evidence in clinical practice in transitional care from hospital to home for older persons as well as demonstration of the new educational leaflets developed.

After implementing best practices, a follow-up audit was carried out in the same way as a baseline audit using the same criteria and data collection instrument, totaling four older people and professionals. There was a difference in the number of older people between baseline and follow-up audits due to the number of hospitalizations, discharges, and length of stay in bed. The results of the compliance percentages of each audited criterion have been compared before and after implementing the best practices, allowing to verify the impact of this project on clinical practice.

\section{RESULTS}

The audited criteria emerged from a systematic search for evidence in the literature.

\section{Baseline Audit}

Seven patients and 10 professionals were included in a baseline audit. The baseline audit compliance rates are shown in Figure 1.

Criteria 1, 3 and 6 had the lowest compliance rates. They were related to absence of specific training in the last six months on transitional care from hospital to home for older persons and nursing records on patient care needs at discharge. However, all older people interviewed reported receiving verbal guidance on self-care at hospital discharge, as indicated by the other criteria analyzed.

\section{"Strategies for Getting Research into Practice" (GRiP)}

With the discussion of the results found in a baseline audit, the project team identified the main barriers to compliance with best practices, and developed strategies to address and overcome them. Chart 2 presents the barriers found, the strategies to overcome them, the necessary resources and the results achieved.

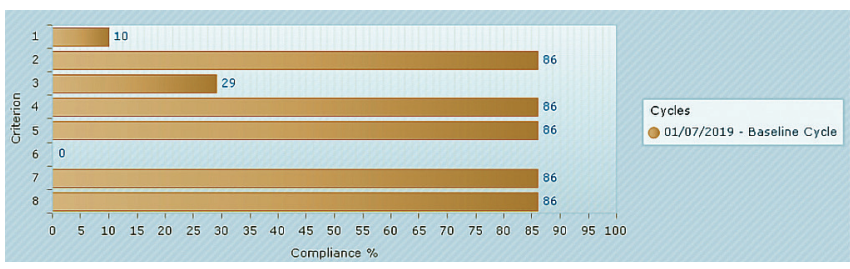

\section{Criteria Legend}

1 All staff involved in transitional care have received education regarding transitional care from hospital to home for older people. (10 of 10 samples taken)

2 Patients/caregivers have received education regarding self-management interventions. (7 of 7 samples taken)

3 An individualized discharge plan has been documented for all patients transitioning from hospital to home. (7 of 7 samples taken)

4 Patients/caregivers have been involved in lhe discharge planning process. (7 of 7 samples taken)

5 Transitional care services have been coordinated between the hospital and community setting. (7 of 7 samples taken)

6 Patient care needs have been communicated between the hospital and community healthcare providers. (7 of 7 samples taken)

7 Post discharge follow-up has occurred. (7 of 7 samples taken)

8 A multifaceted, approach is used for transition ing older people from hospital to home (e.g. may include telephone follow-up, home-based exercise programs, patient-centered discharge instruction) (7 of 7 samples taken)

Figure 1 - "Baseline Compliance with best practice for audit criteria" (\%), São Paulo, Brazil, 2019 
Chart 2 - Best practice implementation, São Paulo, Brazil, 2019

\begin{tabular}{|c|c|c|c|}
\hline Barriers Expected & Strategies & Resources & Results \\
\hline $\begin{array}{l}\text { Absence of an individualized } \\
\text { discharge plan for older people. }\end{array}$ & $\begin{array}{l}\text { Identifying the health needs of older } \\
\text { people based on Activities of daily } \\
\text { living (ADL) and Instrumental Activities } \\
\text { of Daily Living (IADL). }\end{array}$ & Questionnaire. & $\begin{array}{l}\text { Discharge plan implemented } \\
\text { and registration on care } \\
\text { expanded; } \\
\text { It was not achieved due to } \\
\text { the project's implementation } \\
\text { deadline. }\end{array}$ \\
\hline $\begin{array}{l}\text { Falta de conhecimento dos } \\
\text { idosos, cuidadores/ familiares } \\
\text { sobre os cuidados prescritos na } \\
\text { alta hospitalar para casa. }\end{array}$ & $\begin{array}{l}\text { Developing a folder with the main } \\
\text { nursing care, in surgeries, which most } \\
\text { occur with older people, in the surgical } \\
\text { clinic: cholecystectomy, herniorrhaphy } \\
\text { and orthopedic hip surgery. }\end{array}$ & $\begin{array}{l}\text { - Paper sheet A4; } \\
\text { - Photos from the internet and } \\
\text { simulation dummy; } \\
\text { - Computer; } \\
\text { - Hospital communication service. }\end{array}$ & $\begin{array}{l}\text { Development of three } \\
\text { educational folders. However, } \\
\text { they were not delivered to } \\
\text { patients. }\end{array}$ \\
\hline $\begin{array}{l}\text { Absence of a complete record } \\
\text { (health needs) in the medical } \\
\text { record of older patients at } \\
\text { hospital discharge. }\end{array}$ & $\begin{array}{l}\text { Nurses' educational program on } \\
\text { the main aspects to be registered } \\
\text { at hospital discharge - guidelines } \\
\text { provided, documents delivered, } \\
\text { outpatient return, among others. }\end{array}$ & $\begin{array}{l}\text { - Computer (Power Point); } \\
\text { - Conversation round. }\end{array}$ & $80 \%$ of the nurses trained. \\
\hline
\end{tabular}

For "absence of an individualized discharge plan", it was necessary to identify older people needs for self-care at home, when performing ADL (eating, bathing, dressing) and IADL (talking on the phone, shopping, dealing with finances). From this survey, an individualized discharge plan was proposed to be recorded in nursing progress notes of all older patients admitted to the unit, at hospital discharge.

In relation to the lack of knowledge of older people, caregivers/family members, printed educational material was prepared on hospital discharge care, containing instructions on surgeries (herniorrhaphy, cholecystectomy and orthopedic hip surgery), general care and the surgical and surgical wound. return to the clinic. Nurses deliver this form and provide essential verbal guidance.

For the absence of a complete record in the medical records of older people's health needs, training was carried out in the study unit with eight nurses $(80 \%)$, the project coordinator, a head nurse and a Teaching and Quality Service nurse. The importance of carrying out care plans at hospital discharge, recording on the patient's medical record and educational material was discussed. Training took place over a week, lasting approximately 20 minutes, and all participants approved the educational material.

\section{Follow-up audit}

Follow-up audit was conducted 15 days after implementing the intervention packages.

Figure 2 shows the compliance rates of the criteria audited in the follow-up audit, compared with the baseline auditing results.

It was observed that, after training eight nurses $(80 \%)$ on transitional care for home, an individualized discharge plan for all older people (100\%) started to be prepared and recorded in nursing progress notes. All older people (100\%) continued to verbally receive guidance on self-care at home, until the printed educational material was made.

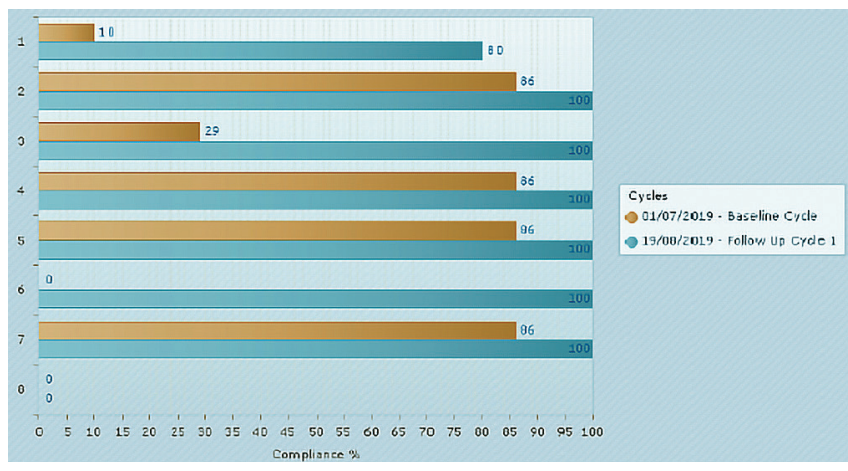

Criteria Legend

1 All staff involved in transitional care have received education regarding transitional care from hospital to home for older people. (10 of 10 samples taken)

2 Patients/caregivers have received education regarding self-management interventions. ( 4 of 4 samples taken)

3 An individualized discharge plan has been documented for all patients transitioning from hospital to home. (4 of 4 samples taken)

4 Patients/caregivers have been invotved in the discharge planning process. ( 4 of 4 samples taken)

5 Transitional care services have been coordinated between the hospital and community setting. (4 of 4 samples taken)

6 Patient care needs have been communicated between the hospital and community healthcare providers. (4 of 4 samples taken)

7 Post discharge fo/low-up has occurred. (4 of 4 samples taken)

8 A multifaceted, approach is used for transitioning older people from hospital to home (e.g. may include telephone follow-up, home-based exercise programs, patient-centered discharge instruction) (4 of 4 samples taken)

Figure 2 - Compliance with best practice audit criteria in follow-up auditing compared to baseline auditing (\%), São Paulo, Brazil, 2019

\section{DISCUSSION}

Transitional care for home plays an important role in healthcare systems. Discharge planning of older patients can be carried out by the entire multidisciplinary team, but it is observed that nurses are often responsible for carrying it out. Discharge planning strengthens the nursing entity itself, its professional autonomy, favoring professional and social development and recognition ${ }^{(16)}$. 
The type of treatment carried out in hospitals may pose a risk to the health of older people at home. Discharge planning is the main channel for hospital for home transition information, and must include information about unavoidable care at hospital discharge.

However, as demonstrated by the present investigation, it is essential to improve the quality of transitional care, especially for older people with complex needs. Considering that cognitive impairment in older people is common, it is necessary to engage caregivers/family members in planning care, in addition to providing written instructions on care required after discharge ${ }^{(17-18)}$. Professionals must prepare patients and their caregivers, actively involving them in decisions related to care plan development and execution. Performance indicators should be developed to measure the effectiveness of transitional care and provide active communication (phone and email) among health professionals and the coordination of care plans for the next level of care ${ }^{(6-7)}$.

Creating a discharge plan with caregivers was associated with a $25 \%$ decrease in readmissions in 90 days and $24 \%$ in 180 days. A meta-synthesis study reported a reduction in hospital stay associated with more prepared and informed caregivers to accompany increasingly complex treatments; moreover, most investigations have observed shorter and less expensive readmissions in post-discharge care(6).

Discharge planning, i.e., developing a personalized plan for each patient who leaves the hospital is a routine feature of health systems in many countries. It aims to reduce hospitalization length and unplanned rehospitalization, in order to contain costs, ensuring that discharge occurs at an appropriate time, in due time, and the provision of services is organized for post-discharge ${ }^{(8,9)}$.

Transitional care takes place in a context that includes patients, their families and caregivers, and the professionals who provided care and those who will continue to care. Therefore, it is a complex process that requires coordination and communication between people of different backgrounds, experiences and skills. Hospital discharge is a time of change in patients' daily lives, with the addition of medications and home care. These changes are sometimes not addressed effectively during hospitalization, providing fragmentation of post-discharge care. It is a moment that requires planning, preparation and health education for patient and family, especially older people and people with chronic diseases, who have persistent health needs. However, discharge instructions are often carried out mechanically and/or in a hurry and without considering the conditions and needs of each patient, often provided only when leaving the hospital (19).

Education strategies developed using clear and objective communication, use of simple language, illustrative inserts and information feedback contribute to the understanding of care by patients and family members. The guidelines provided by nurses are essential for successful transitions, as they favor medication use and self-care management, increase adherence to treatment, decrease readmission and mortality rates. Higher quality transition processes presuppose a focus on the individual needs of patient and family and shared care; therefore, professionals, patients and family members become partners in care, from the moment of hospitalization until the days after returning home ${ }^{(19)}$.
Hospital managers and caregivers need to implement consistent transitional car strategies to prevent events, which generate return visits to the emergency department or hospital. Coordination of care transitions is especially important for patients with diverse health needs and multiple comorbidities. These patients are often dependent on technologies and devices for continuity of care in their homes or other places of care and require trained professionals and support resources at discharge ${ }^{(20)}$.

Nurses' work is fundamental in the implementation of educational actions; strategies to increase adherence to treatment; creation of personalized care plans, based on the needs of patients; post-discharge monitoring of patients through home visits and phone calls; primary care team training. Nurses, members of multidisciplinary teams, are qualified agents for carrying out activities related to health promotion and protection, as they have extensive knowledge of their training and follow patients during most of their hospital stay, especially in institutional settings ${ }^{(20)}$.

Some resources were identified for structuring the work of multidisciplinary teams in planning discharge. Discharge protocols and management plans for discharge have been presented as a basis for the linearity of care (during and after hospitalization), since they favor a thorough assessment of patients' needs and positively influence the work of the teams by providing perspectives of comprehensiveness of health actions and action planning. The resources used for health education can be considered fundamental for the proper management of care and the recovery of patients' health. In this regard, through written educational materials, audio tapes and post-discharge telephone follow-up, nurses teach and reinforce care for recovery and/or maintenance of post-discharge health ${ }^{(21) .}$

A strategy for patient-centered discharge planning and communication between the multidisciplinary team integrated specialized primary care and social services with hospital discharge as well as the implementation of electronic health records (electronic medical records) and printed care plan. Therefore, hospital service professionals and the community can access relevant online information from patients for continuity of care, in order to guarantee patients safe discharge and continuity of care ${ }^{(22)}$.

During transitional care, customers/individuals must feel situated, i.e., be a comprehensive part of the context in which they are inserted. This pattern is indispensable, because transitioning involves creating new meanings and perceptions and reformulating meanings in relation to the environment. This is a dynamic state that leads us to the notion of adapting to the environment, and subsequently to the development of trust, which occurs when transitioning, demonstrating a deeper knowledge, as well as a greater understanding about the essential and critical aspects ${ }^{(23)}$.

Finally, carrying out studies related to transitional care is encouraged, especially considering specific populations, such as older surgical or clinical patients, describing the best strategies and interventions.

\section{Study limitations}

The sampling of patients followed up, time for monitoring interventions, and consolidating the implemented actions were the main limitations. Thus, it is suggested that further studies extend the deadlines for carrying out audits and follow-up, with 
a larger sample size and monitoring of complications related to patients' health.

\section{Contributions to nursing}

This study contributes to nursing by presenting an international method for implementing better evidence. It suggests tools and demonstrates the feasibility of implementing a transitional care plan for older people from hospital to home with positive results, with low financial investment and in a short period of time.

\section{FINAL CONSIDERATIONS}

This project contributed to the implementation of best practices based on satisfactory and more adequate evidence in transitional care from a Brazilian university hospital to home for older people.

Through this audit, several strategies have been used, including nurse training, protocol development and preparation of educational material with guidelines for home care. However, this project demonstrates the need to increase compliance rates of some criteria to $100 \%$ through permanent education of the entire team that assists older people and cyclical follow-up audits that allow to continuously assess the implementation of this best evidence-based practice. Such practice can have a major impact on care and health of these patients as well as contribute to developing public policies and referral and counter-referral system in the Health Care Network (Rede de Atenção à Saúde).

\section{REFERENCES}

1. Sousa SM, Bernardino E, Crozeta K, Peres AM, Lacerda MR. Integrality of care: challenges for the nurse practice. Rev Bras Enferm. 2017;70(3):504-10. doi: 10.1590/0034-7167-2016-0380

2. Campolina AG, Dini PS, Ciconelli RM. The impact of chronic disease on the quality of life of the elderly in São Paulo (SP, Brazil). Cien Saude Colet. 2011;16(6):2919-25. doi: 10.1590/S1413-81232011000600029

3. Peiter CC, Santos JLG, GMM Lanzoni, Mello ALSF, Costa MFBNA, Andrade SR; et al. Healthcare networks: trends of knowledge development in Brazil. Esc Anna Nery 2019;23(1):e20180214. doi: 10.1590/2177-9465-EAN-2018-0214

4. Ministério da Saúde (BR). Secretaria de Vigilância em Saúde. Departamento de Análise de Situação de Saúde. Plano de ações estratégicas para o enfrentamento das doenças crônicas não transmissíveis (DCNT) no Brasil 2011-2022. 2011. Brasília: MS.

5. Allen J, Hutchinson A, Brown R, Livingston P. Quality care outcomes following transitional care interventions for older people from hospital to home: a systematic review. BMC Health Serv Res. 2014;14(346). doi: 10.1186/1472-6963-14-346

6. Allen J, Hutchinson AM, Brown R, Livingston PM. User experience and care integration in transitional care for older people from hospital to home: a meta-synthesis. Qual Health Res. 2017;27(1):24-36. doi: 10.1177/1049732316658267

7. Courtney MD, Edwards HE, Chang AM, Parker AW, Finlayson K, Bradbury C, et al. Improved functional ability and independence in activities of daily living for older adults at high risk of hospital readmission: a randomized controlled trial. J Eval Clin Pract. 2012;18(1):128-34. doi: 10.1111/j.1365-2753.2010.01547.x

8. Aued GK, Bernardino E, Lapierre J, Dallaire C. Liaison nurse activities ate hospital discharge: a strategy for continuity of care. Rev Latino-Am. Enfermagem. 2019;27:e3162. doi: 10.10.1590/1518-8345.3069.3162

9. Goncalves-Bradley DC, Lannin NA, Clemson LM, Cameron ID, Shepperd S. Discharge planning from hospital. Cochrane Database Syst Rev. 2016;(1):CD000313. doi: 10.1002/14651858. CD000313.pub5

10. Ribas EN, Bernardino E, Larocca LM, Poli Neto P, Aued GK, Silva CPC. Nurse liaison: a strategy for counter-referral. Rev Bras Enferm. 2018;71(Suppl 1):546-53. doi: 10.1590/0034-7167-2017-0490

11. Costa MFBNA, Andrade SR, Soares CF, Ballesteros Pérez El, Capilla Tomás S, Bernardino E, et al. The continuity of hospital nursing care for Primary Health Care in Spain. Rev Esc Enferm USP. 2019;53:e03477. doi: 10.1590/S1980-220X2018017803477

12. The Joanna Briggs Institute (JBI). The new JBI Grades of recommendations [Internet]. The University of Adelaide; 2013 [cited 2016 Dec 20 ]. Available from: http://joannabiggs.org/assets/docs/approach/JBI-grades-of\%20recomemendation

13. The Joanna Briggs Institute (JBI). Breastfeeding: Engorgement. Best Practice Information Sheet. 2016.

14. Nobre IEAM, Barros LM, Gomes MLS, Silva LA, Lima CS, Caetano JA, et al. Sistema de Classificação de paciente de Fugulin: perfil assistencial da clínica médica. Rev Enferm UFPE. 2017;11(4):1736-42. doi: 10.5205/reuol.9763-85423-1-SM.1104201723

15. Siqueira TH, Vila VSC, Weiss ME. Cross-cultural adaptation of the instrument Readiness for Hospital Discharge Scale: adult form. Rev Bras Enferm. 2018;71(3):983-91. doi: 10.1590/0034-7167-2017-0241

16. Weber LAF, Lima MADS, Acosta AM. Quality of care transition and it Association with hospital readmission. Aquichan. 2019;19(4):e1945. doi: 10.5294/aqui.2019.19.4.5

17. Robelia PM, Kashiwagi DT, Jenkins SM, Newman JS, Sorita A. Information transfer and the hospital discharge summary: national primary care provider perspectives of challenges and opportunities. J Am Board Fam Med. 2017;30(6):758-65. doi: 10.3122/jabfm.2017.06.170194

18. Mixon AS, Goggins K, Bell SP, Vasilevskis EE, Nwosu S, Schildcrout JS, et al. Preparedness for hospital discharge and prediction of readmission. J Hosp Med. 2016;11(9):603-9. doi: 10.1002/jhm.2572 
19. Weber LAF, Lima MADS, Acosta AM, Marques GQ. Transição do cuidado do hospital para o domicílio: revisão integrativa. Cogitare Enferm. 2017;(22)3:e47615. doi: 10.5380/ce.v22i3.47615

20. Lima MADS, Magalhães AMM, Oelke ND, Marques GQ, Lorenzini E, Weber LAF, et al. Care transition strategies in Latin American countries: an integrative review. Rev Gaúcha Enferm. 2018;39:e20180119. doi: 10.1590/1983-1447.2018.20180119

21. Cruz IM, Mantovani MF. Orientação de Enfermagem para a alta hospitalar do paciente neoplásico. Cogitare Enferm. 2014;19(4):687-93. doi: 10.5380/ce.v19i4.36261

22. Cieto BB, Garbuio DC, Camargo VB, Napoleão AA. Recursos e inovações de enfermagem para a alta: revisão integrativa. Rev Min Enferm. 2014;18(3):752-63. doi: 10.5935/1415-2762.20140055

23. Santos E, Marcelino L, Abrantes L, Marques C, Correia R, Coutinho E, et al. O cuidado humano transicional como foco da enfermagem: contributos das competências especializadas e linguagem classificada CIPE ${ }^{\circledR}$ Millenium [Internet]. 2015[cited 2016 Dec 20];49:153-71. Available from: https://revistas.rcaap.pt/millenium/article/view/8083 